\title{
THE ASSESSMENT OF KNOWLEDGE OF ORGANISATIONAL - ADMINISTRATIVE PROCEDURES IN THE CASE OF A BIOTERRORIST THREAT IN SELECTED ENVIRONMENTAL POPULATIONS
}

\author{
Gabriela Henrykowska, Marcin Lipiński, Maria Dziedziaczak - Buczyńska, Magdalena Zawadzka,
} Małgorzata Lewicka, Andrzej Buczyński

Department of Epidemiology and Public Health, Medical University of Łódź

\begin{abstract}
In the past we have seen numerous cases of the purposeful utilisation of micro-organisms and toxins. This situation forced us to undertake actions aimed at a limitation of the production and storage of biological weapons. Unfortunately, despite the signing of the Convention on Biological and Chemical Weapons, many countries are still involved in research into the use of biological agents as a military resource.

The objective of the work was to perform an assessment of the knowledge of threats connected with bioterrorism as well as of the procedures in the case of a bioterrorist attack in two different urban populations - i.e. of below 50 thousand and above 500 thousand inhabitants.

The study was conducted in two towns, Nysa and Łódź. A self-designed questionnaire included 100 persons from each town, both men and women aged between 18 and 65 years. Despite the small differences between the researched populations, the knowledge of respondents concerning bioterrorist threats and procedures during an attack is insufficient.

On the basis of the obtained results we may conclude that there is a need to educate the entire society, irrespective of the place of residence, in order to raise an awareness with regard to the potential threat and procedures in the event of a bioterrorist attack. Key words: bioterrorism, administrative-organisational procedures, population's behaviour during threat.
\end{abstract}

\section{ARTICLE INFO}

PolHypRes 2016 Vol. 57 Issue 4 pp. 65 - 74

ISSN: 1734-7009 eISSN: 2084-0535

DOI: $10.1515 /$ phr-2016-0027

Pages: 10 , figures: 6 , tables: 0

page www of the periodical: www.phr.net.pl

Publisher

Polish Hyperbaric Medicine and Technology Society
Rewiev article

Submission date: $24.11 .2016 r$

Acceptance for print: 22.12.2016r. 


\section{INTRODUCTION}

The threatening factor in bioterrorism consists of the risk of the use of, or the utilisation of biologically, chemically or toxically active substances or pathogens inducing dangerous diseases, including infectious ones. A bioterrorist attack is always aimed at humans/a society, however potentially it could also target domestic animals, crops, food, potable water, etc. $[1,2]$.

There are multiple pathogens that induce infectious diseases in people and animals, however the production of biological weapons is mainly based on the use of bacteria and viruses; this being essentially due to the low cost of bacteria production and the potential to produce them over a very short time $[3,4,5]$.

Such weapons are easily accessible, cheap to produce and difficult to detect [6]. The most frightening form of use is in aerosols or via the application of an agent to ventilation systems. This causes fast and mass infections in the population, as well as high mortality $[7,8,9]$. In the fight against the effects of an attack, early detection of a biological agent is crucial. [10,11].

The priority is that each citizen be familiar with the procedures and algorithms of conduct to be applied in the case of a bioterrorist attack. Another important element consists in the ability to detect the threat when nobody expects it $[12,13,14]$.

\section{OBJECTIVE}

The objective of the study was to evaluate the knowledge of selected populations, with regard to threats connected with bioterrorism and procedures, in the event of a bioterrorist attack. Moreover, it aimed to verify whether the said knowledge depends on the respondents' place of residence.

\section{MATERIAL AND RESEARCH METHODS}

The research was conducted among 200 randomly chosen subjects, both men and women aged between 18-65 years, residing in different urban agglomerations. The inhabitants of Nysa (100 persons) represented an agglomeration below 50 thousand inhabitants, whereas residents of Łódź (100 persons) an agglomeration above 500 thousand inhabitants. Among the respondents from Łódź $61 \%$ were women, whereas from Nysa 35\%. Men constituted 39\% and 65\% respectively. The most numerously represented group in both towns were subjects aged between 18 and 30 years.

The study was based on a diagnostic survey. It was carried out with a self-designed questionnaire consisting of open and closed questions, multiple-choice questions and respondents' particulars.

The work was based on a statistical analysis by means of test Chi-square and C-Pearson correlation coefficient at the adopted significance level of $p<0.05$. The obtained data were subject to descriptive and statistical analysis. The results were described with a structure indicator - frequency, on the basis of percentage values and fractions.

The study was approved by the Bioethics Committee of the Medical University of Łódź.

\section{RESEARCH RESULTS AND DISCUSSION}

$86 \%$ of respondents from both agglomerations declared that they understand the term "biological weapon" (fig.1). They enumerated biological substances pathogens, which may be used during a bioterrorist attack, such as: viruses, bacteria or their spores. A statistically significant difference between the place of residence and declared knowledge on biological weapons was not noted.

According to the studies conducted by Bartosiński et al. every $8^{\text {th }}$ student of the Medical Academy of Lublin was not able to identify even a single agent which could be used as a biological weapon. Correct responses were provided by nearly half of those surveyed [15].

In the course of own studies the majority of respondents $(62 \%)$ from both towns were able to enumerate biological agents that may be used as a biological weapon. They provided the following examples: anthrax bacteria, plague inducing bacteria, smallpox virus, francisella tularensis, fungi. Respondents from Nysa additionally enumerated castor oil and botulin.

The answers provided by the respondents did not include substances erroneously enumerated as potentially usable as a biological weapon. Similar results were obtained also by other authors [16]. In the research conducted by Bartosiński et al. the most commonly mentioned pathogens were: Bacillus anthracis - 33.7\% and smallpox $-30.77 \%$. Only $2 \%$ of those surveyed indicated that none of the listed diseases entail any risk [15].

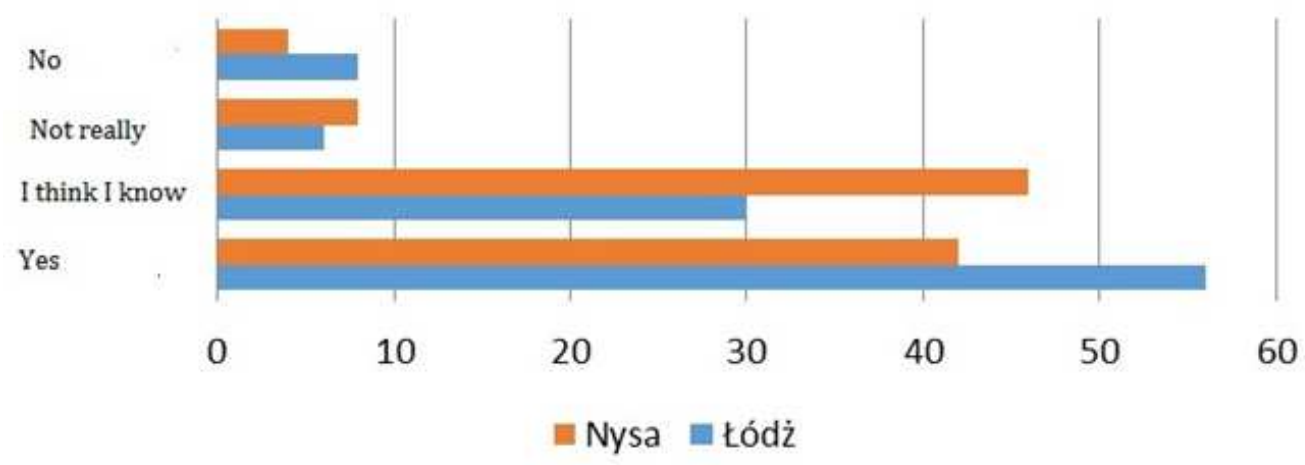

Fig. 1 The knowledge of the term 'biological weapon' in the opinion of respondents. 
$88 \%$ of inhabitants of Nysa and $93 \%$ of inhabitants of Łódź pointed to the Internet as a basic and the most accessible source of knowledge on biological weapons, bioterrorism, and procedures in the event of a threat.

Further ranks (with minimal score differences) were taken by the press, television and radio. Only a few respondents indicated specialist literature as their source of knowledge. In the studies of other authors, the main sources of information on bioterrorism were television $67.96 \%$ and the press $-69.29 \%$ [15].

There are numerous characteristic symptoms which may indicate an attack with the use of biological weapons $[5,9,17]$. These include:

a. High incidence of a disease with no logical explanation, deaths occurring around the same time characterised by a similar clinical presentation, symptoms indicating damage to the respiratory or alimentary system;

b. A single case of a disease with the presence of an exotic biological agent in a person who had not left the country;

c. Sudden increase in the incidence or morbidity due to unknown diseases; d. Occurrence of abnormal symptoms;

e. Atypical spread of diseases.

The contamination usually occurs through breathing of contaminated air, penetration of pathogenic micro-organisms through the skin or conjunctivae, consumption of contaminated food and water and bites by infected insects [1,3]. The effect of biological contamination of humans may be the development of fatal infectious diseases in their organisms [5].

Only $60 \%$ of inhabitants of Łódź and $62 \%$ of inhabitants of Nysa declared being familiar with the possible methods of spreading biological weapons. The replies of respondents from both towns were very similar. They mainly included: aerosols, smoke from a plane, unidentified substances sent by post, water or food contamination and spraying of substances in the air. $100 \%$ of the respondents from Łódź and $80 \%$ of inhabitants of Nysa declared their ability to recognise a bioterrorist attack. Unfortunately, over $50 \%$ of inhabitants of each agglomeration were not able to indicate all of the 3 typical signals suggesting an occurrence of an attack (Fig.2). smoke, fog, dust occurring after a plane flies by

multiple deaths and infections with similar symptoms and of unknown etiology

mass deaths among domestic animals

all of the above statements are correct

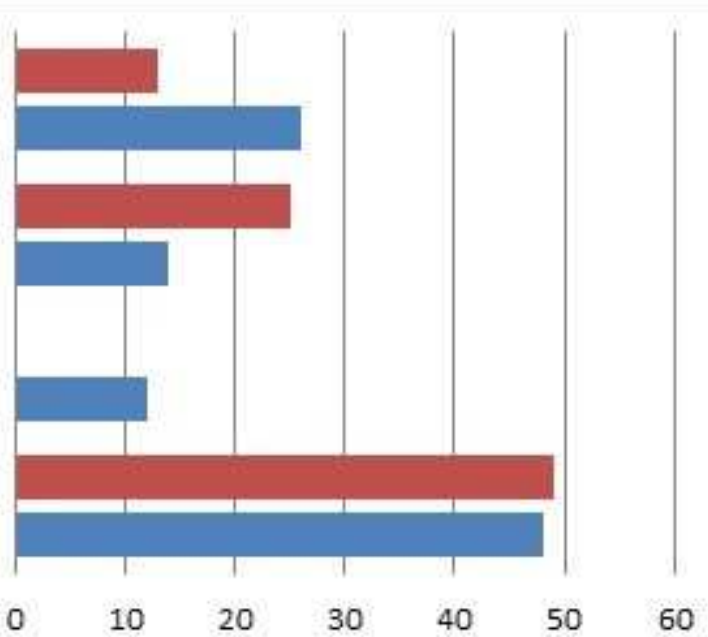

Łódź nysa

Fig. 2. The respondents' ability to recognise a bio-terrorist attack.

If terrorists themselves or proper services do not inform us of this fact, there is a large chance that we will learn of a bio-terrorist atack several days after its occurrence. The first signs will consists in mass infections and deaths - and not in a black cloud hanging threateningly over the city [18], as $17 \%$ of the respondents seem to think.

It is easy to lose control over the effects of a terrorist attack involving the use of biological or chemical weapons, which makes such attacks particularly dangerous. Once they are released, biological agents may lead to a significant number of deaths and infections. $[6,8]$. Hence, in a situation of a risk of a bio-terrorist attack it is vital to notify competent institutions, up to the highest levels of authority, to deal with the discussed problem. These start from the District Sanitary Inspector, trough District Crisis Management Centre, to the Ministry of Internal Affairs and Administration and the Committee of the Council of Ministers for Crisis Management. This will allow implementation of proper procedures and coordination of actions in the event of a threat of a bioterrorist attack $[10,12,13]$.

As many as $24 \%$ of respondents from Nysa and $22 \%$ from Łódź declared their lack of knowledge concerning procedures in the case of a suspicion of a bioterrorist attack. Slightly over $60 \%$ of inhabitants of both agglomerations would act correctly in an occurred situation, without leading to the dissemination of a potential disease and await instructions from rescue services (fig.3). 


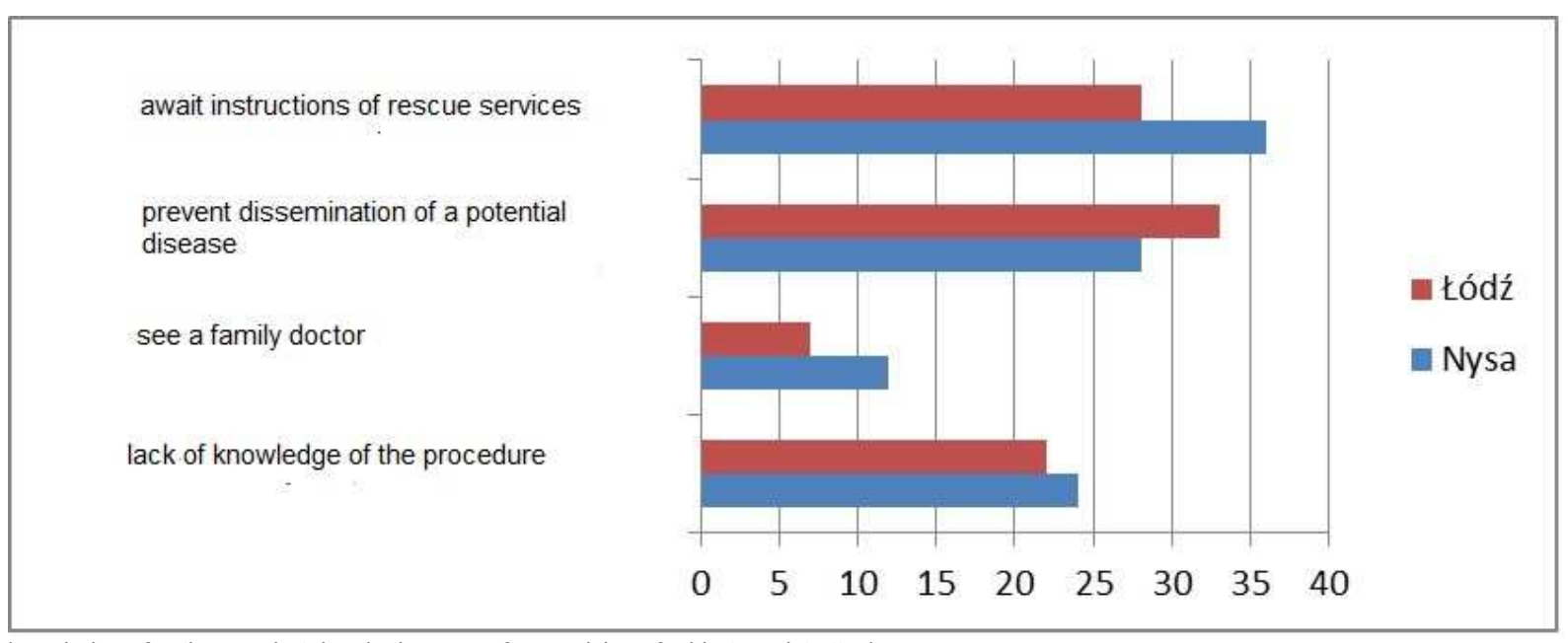

Fig. 3. The knowledge of actions undertaken in the case of a suspicion of a bio-terrorist attack.

In the case of receiving a suspiciously looking parcel or letter, over half of the respondens from both agglomerations would open it to check its contents. Another, most common reaction was to throw it away. Approximately $1 / 3$ of those researched deemed it reasonable to secure the said parcel or letter and notify the rescue services (Fig.4). In the studies of other authors, $86.81 \%$ of respondents replied that they would leave such a parcel or letter intact and inform the police or the fire department. What is interesting is that $8 \%$ of respondents would return an intact parcel to the post office, whereas $2 \%$ would throw it away [15].

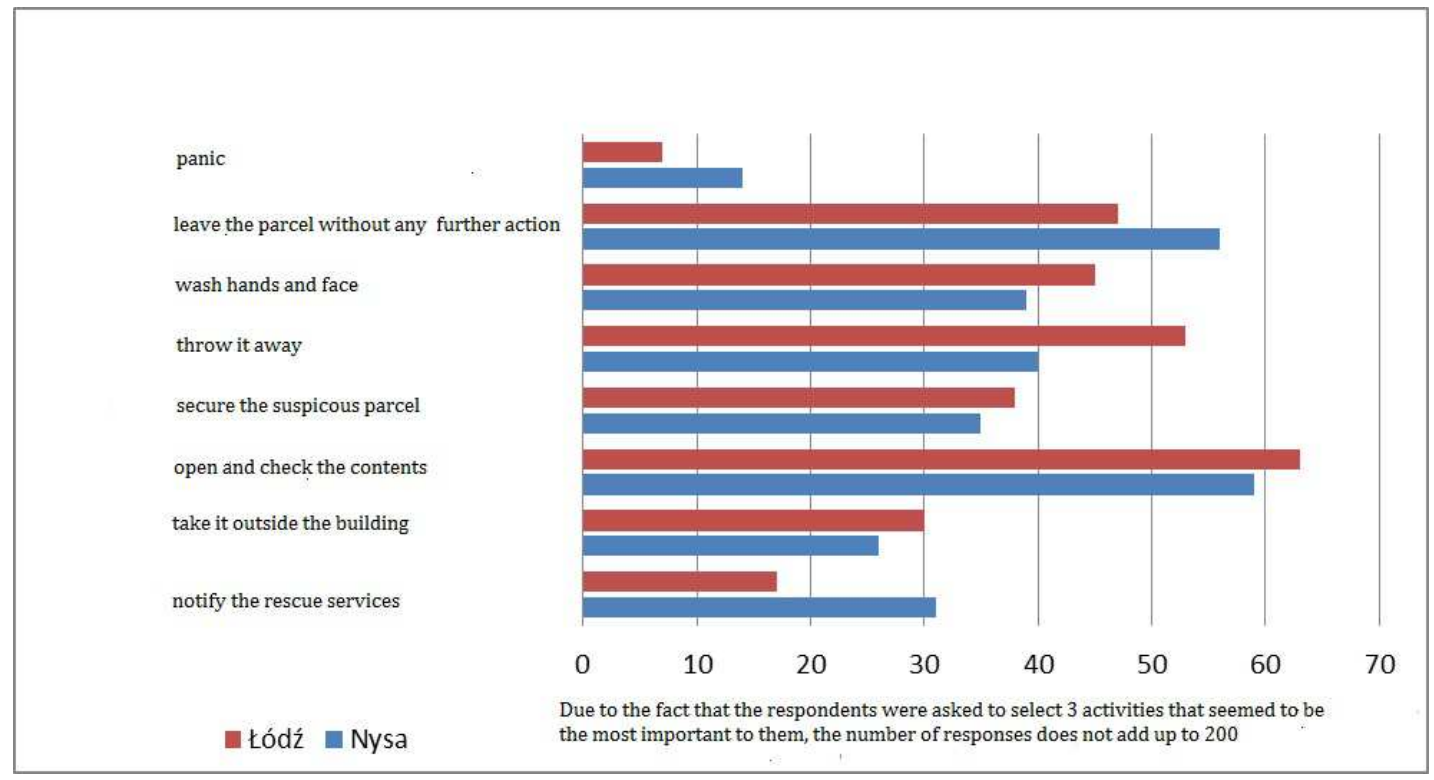

Fig. 4. The declared actions of the respondents in the case of a reception of a parcel or letter of unknown origin.

In the event of a suspicion of utilisation of biological weapons in a building where we are at a given moment, only $33 \%$ of the respondents from Łódź and $21 \%$ of inhabitans of Nysa would do the right thing by moving to the highest room, closing the windows, doors and switching off the ventilation system to prevent the chemical or biological substance from spreading faster. Unfortunately, $13 \%$ of the respondents from Łódź and $23 \%$ from Nysa would immediately go to hospital, which could cause a more rapid dissemination of a potentially infectious biological agent (fig.5). 


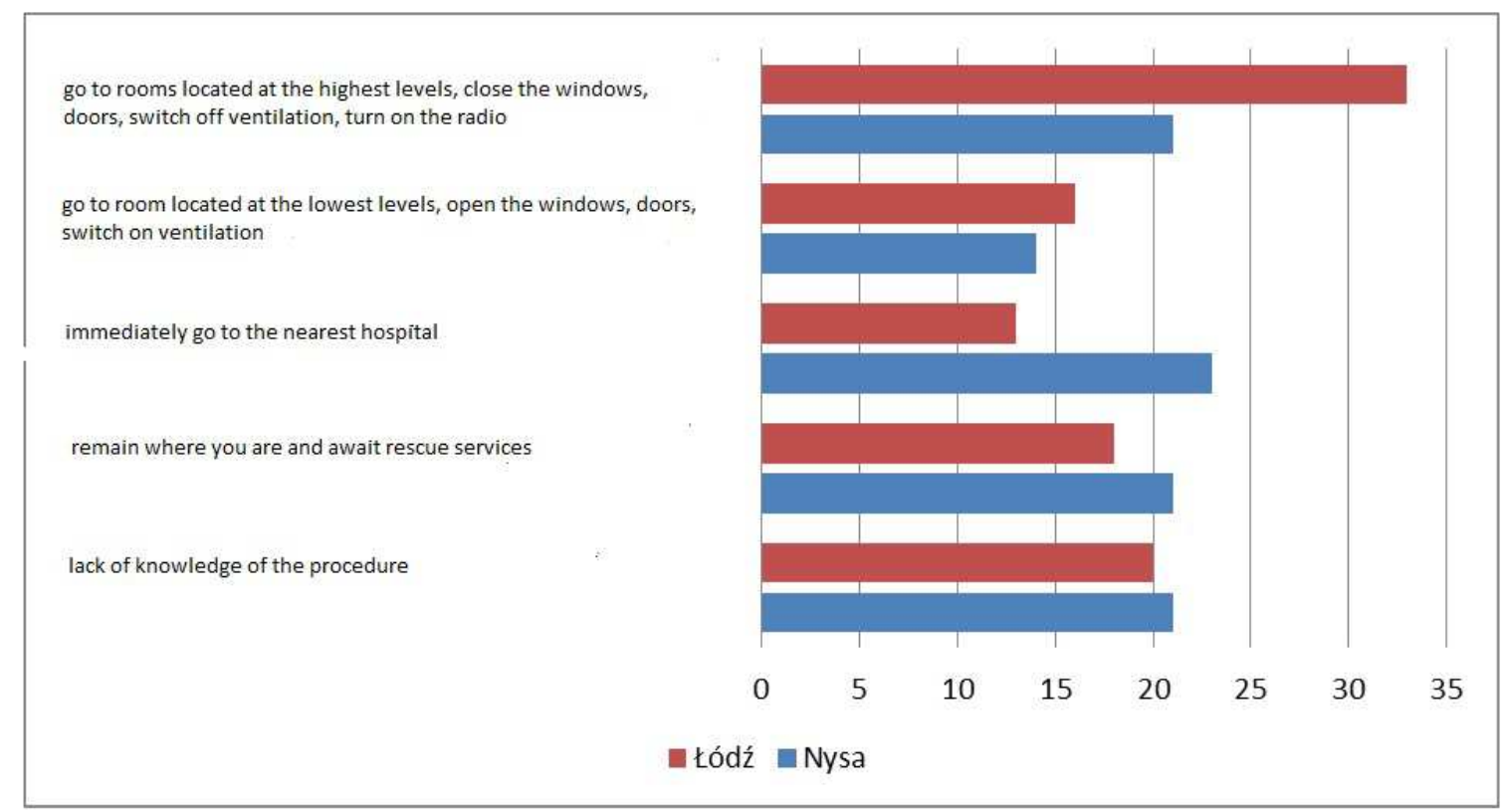

Fig. 5. The knowledge of the procedure in a situation of a bio-terrorist attack in a building where the respodents are currently staying.

Slightly more than a half of the inhabitants of Łódź (51\%) and $40 \%$ of the inhabitants of Nysa would proceed correctly if a bio-terrorist attack took place in an open area (fig.6). Unfortunately, the average of $16 \%$ of the respondents declared their lack of knowledge of the procedure in such a case.

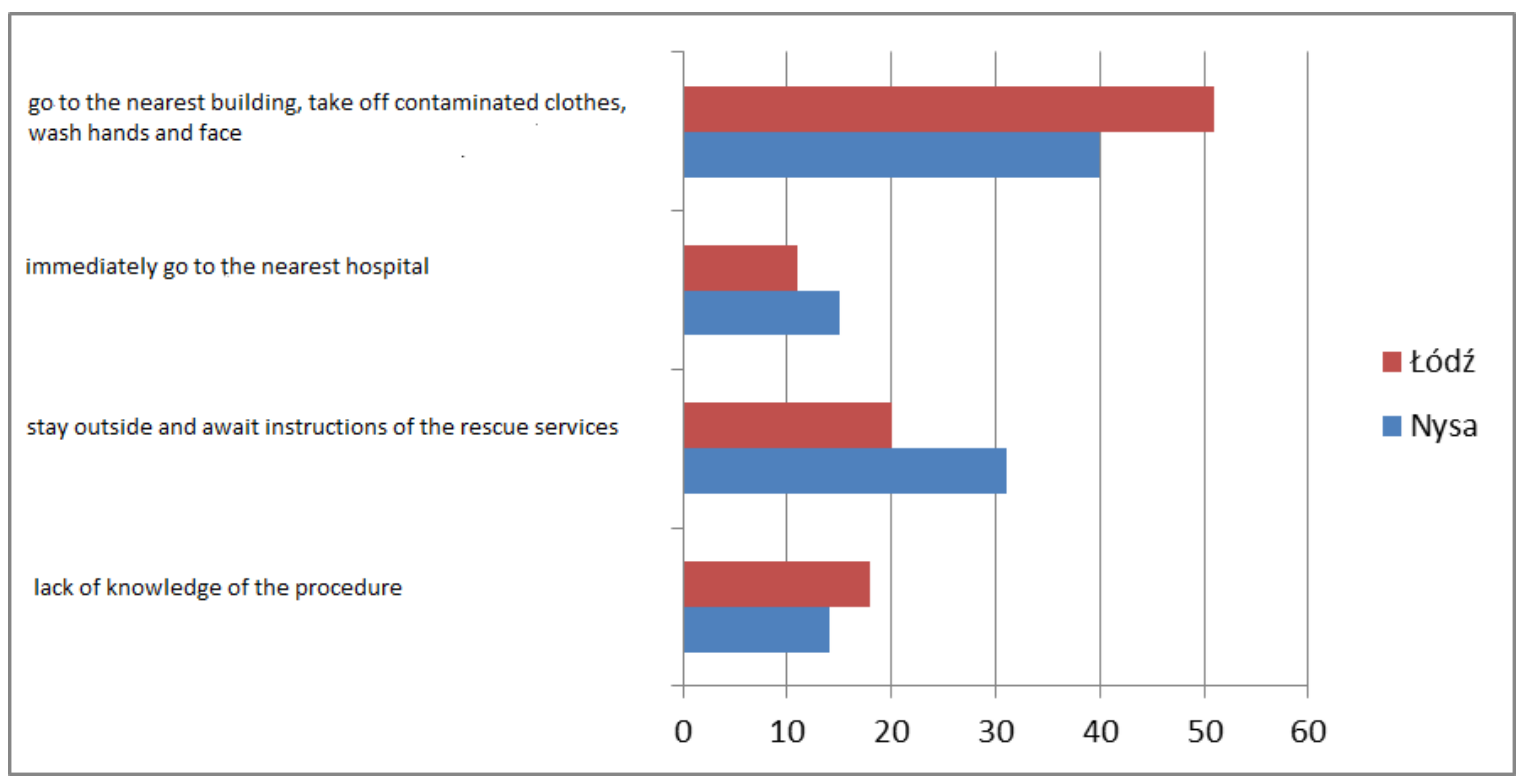

Fig. 6. The knowledge of the procedure among those surveyd in a situation of an occurrence of a bio-terrorist attack in an open area.

A vast majority of respondents $(86 \%)$ fear that the authorities of their towns are not sufficiently prepared for an occurrence of a bioterrorist attack and do not know how to act in the situation of a threat.

The level of safety in the country would be much higher if rescue crews joined forces with the society $[12,13]$. Teaching citizens the procedures or proper behaviour is much more efficient than imposing top-down directives. Simulations of dangerous situations should be conducted in the presence of civilian populations and not just by professionals. Educational campaigns concerned with the avoidance of panic, first aid provision or evacuation should be carried out in each town [19].

Own studies confirm that by the respondents' pointing to the necessity to implement educational activities in their towns with the purpose of preparing the 
society to a bioterrorist attack.

\section{CONCLUSIONS}

1. The awareness of threats connected with bioterrorism and knowledge of procedures in the case of a bioterrorist attack among the inhabitants of both agglomerations is at a similar level and can be assessed as insufficient.

2. In the majority of cases, the place of residence of respondents did not have a significant effect on their knowledge on the analysed subject matter and procedures in the case of a suspected bioterrorist attack.

1. There is a need to educate the entire society, irrespective of the place of residence, for the purpose of raising their awareness regarding a potential threat and procedures in the event of a bioterrorist attack.

\section{BIBLIOGRAPHY}

Chomiczewski H. The threat of bioterrorism. Przeglad Epidemiologiczny, 2003, 57:349-53;

Binczycka-Anholcer M, Imiołek A. Bioterrorism as one of the forms of modern terrorism. Hygeia Public Health 2011, 46(3): 326-333;

Khan AS, Morse S. Lillibrgidge S. Public-health preparedness for biological terrorism in the USA. Lancet 2000,356:1179-82;

Puzanowska B. Bioterrorrism. Przegląd Epidemiologiczny, 2001,. 55:379-86;

Gerstein DM. Bioterror in the age of biotechnology. JFQ 2010;57(2):78-85;

Grosset R. To exterminate thousands and threaten millions. Terrorist threats and chances for effective defence. Warsaw: 2009;

Mirski T. Review of methods used for identification of biothreat agents in environmental protection and human health aspects. Annals of agricultural and environmental medicine, 2014, 21 (2): 366-381;

8'Agostino M, Martin G. The bioscience revolution \& the biological weapons threat: levers \& interventions. Global Health 2009;5:3

9. Nahid A, Masoumeh BN. Bioterrorism education effect on knowledge and attitudes of nurses, Journal of Emergencies, Trauma, and Shock, 2013, 6:2;

10. Machnikowski M. Poland as a potential target of a terrorist attack. Wyższa Szkoła studiów Międzynarodowych w Łodzi. Łódź, 2007;

11. Kaufmann AF, Meltzer MI, Schmid GP. The Economic Impact of a Bioterroristic Attack: Are Prevention and Postattack Intervention Programs Justifable Emerg Inf Dis 1997;

12. Zubrzycki W. Terrorist threat prevention in Poland. Warsaw 2011;

13. Ćwiek - Karpowicz. Poland in the face of a bioterrorist attack. Proper preparation and efficient responding for the minimisation of the results of a tragedy. Instytut Spraw Publicznych. 2006

14. May T. Bioterror and Public Health Infrastructure: A Response to Commentators, The American Journal of Bioethics, 2006 6(1): W29-W31:

15. Bartosiński. J.. Miotła P., Wdowiak L. The knowledge of students of the Medical Academy of Lublin on bioterrorism. Zdr. Publ. 2004 114 (4), 487-490;

16. Weant KA; Bailey AM; Fleishaker EL; Justice SB, Being prepared: bioterrorism and mass prophylaxis: part I. Advanced Emergency Nursing Journal, 2014, 36 (3), 226-38

17. Strojek M. The contemporary threat with biological weapons - bioterrorism. Med Ogólna 2008, 2;

18. Michailiuk B. Biological weapons as a threat to state security. AON, 2015.

19. Szafrański J. Cooperation between territorial defence units and the police in the fight against terrorism. Szczytno: 2004

dr n. med. Gabriela Henrykowska

Zakład Epidemiologii i Zdrowia Publicznego,

Uniwersytet Medyczny w Łodzi

e-mail: gabriela.henrykowska@umed.lodz.pl 